\title{
Exemplary leadership practices in early childhood education in preparing the golden generations for Indonesia
}

Usnul Umi Miftahurrohmah $^{1^{*}}$, Hasan Hariri ${ }^{2}$, Riswanti Rini ${ }^{3}$, Rohmatillah $^{4}$

Preschool Principal, Sekolah Darma Bangsa, Bandarlampung, Indonesia ${ }^{{ }^{*}}$

Faculty of Teacher Training and Education, Universitas Lampung, Bandar Lampung, Indonesia ${ }^{2,3}$

English Department, Raden Intan State Islamic University, Bandar Lampung, Indonesia ${ }^{4}$

umisdb@darmabangsa.sch.id ${ }^{1}$, hasantownsville@gmail.com ${ }^{2}$, $\underline{\text { riswanti.rini@gmail.com }}^{3}$,

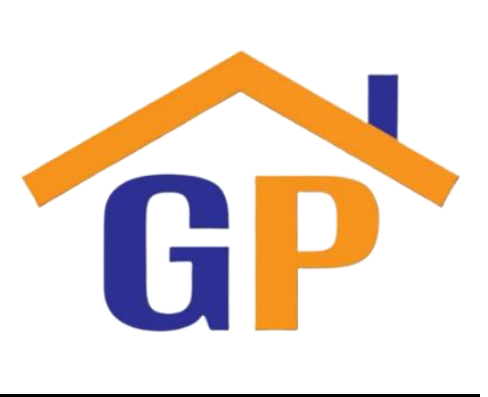

Article History

Received on 13 April 2021

Revised on 1 May 2021

Accepted on 4 May 2021

\begin{abstract}
Purpose: This study aimed to investigate the ideal quality of inclusive early childhood education, an effective leadership style and five practices of exemplary leadership.
\end{abstract}

Research methodology: This is a review article. The review process began with a search engine (Google Scholar) to search and review early childhood education and leadership articles.

Results: The results suggest that it is important to hold quality inclusive early childhood educations since, in this level of education, six developmental areas are well stimulated. The key success of maintaining quality inclusive early childhood education is a collaboration among education parties (government, school, parents and community). A school needs a principal who can perform five exemplary leadership practices to help "Golden Indonesia 2045" become true.

Limitations: First, the scope of articles reviewed is still very limited to the literature review in the Indonesian context. This and other limitations will be opportunities for further empirical studies about five practices of exemplary leadership in the Indonesian education area.

Contribution: This study can be useful for the early childhood education level.

Keywords: Golden generation, Inclusive, Early childhood education, Leader, Leadership styles, Exemplary leadership, Principal, Transformational leadership style

How to cite: Miftahurrohmah, U. U., Hariri, H., \& Rini, R., \& Rohmatillah. (2021). Exemplary leadership practices in early childhood education in preparing the golden generations for Indonesia, Journal of Social, Humanity, and Education, 1(4), 253268.

\section{Introduction}

Indonesia has prepared for its 100th independence day, known as "Golden Indonesia," in 2045. In its celebration, Indonesia is going to get a demography bonus between 2030 and 2045. In this period, the Indonesian population is in productive ages, ranging from 35 to 45 . This is an advantage for Indonesia, where its people have a high capacity for thinking and working and a good health condition. The major thing for Indonesia towards "Golden Indonesia" in 2045 is preparing for its human resource. Education plays an important role in human resource development. In particular, it is necessary to pay more attention to early childhood education as a basic foundation of education (Jamrah, 2017) and an effective leader for building the human resource for future generations (Indonesian Golden Generation). 
Indonesian Golden Generation is a generation given provision to be able to help make Indonesia a developed country. Education contributes to future generations because it is a key to presenting credible human resources. Education is also able to change behavior and increase human knowledge (Darman, 2017). As well as Indonesia, the government of Oman has realized that the important factor of developing humans as a sustainable resource for the country's prosperity is education (Kooli, 2017). Given that early childhood education takes an essential role in preparing for future generations, the Indonesian government has made policies regarding early childhood education containing Early Childhood Education National Standard and Early Childhood Education National Curriculum (Permendikbud, 2014a, 2014b).

There are four early childhood education parties: government, school, parent, and community. The government takes roles as an education policymaker and supervisor, school as an education executor, while parents and district as an education partner that can support and evaluate school's program. These four education parties should synergize for a high quality of early childhood education. It is important in early childhood education to implement inclusive schools that facilitate children with developmental delays or special needs children, or developmental disabilities.

The number of children with a developmental delay has increased. Indonesian Central Bureau of Statistics noted that there were 1.6 million children with developmental delay in Indonesia (BPSStatistics, 2017). The number of children with developmental delay is getting bigger by years; thus, we have to be aware that all children will be future generations, including those with developmental delay. They are part of the community. They have the same right and responsibilities as God's creatures and as citizens. As citizens, they are supposed to participate actively in developing Indonesia, not as the burden of national development. The Indonesian government assures that children with developmental delays have suitable for education access (Permendiknas, 2009).

In May 2015, the world forum of education reaffirmed its commitment to inclusive education with the Inch Eon Declaration and the Education 2030 Framework for Action. The declaration ensures inclusive and equitable quality education and promotes lifelong learning opportunities for all. Inclusive and equity in education are essential to make sure that everyone will have access to education.

Aligned with Inch Eon Declaration and the Education 2030 Framework for Action, the education philosophy in Oman is a combination between modernism (life long learning, knowledge, technology, research innovation, responsibility, human right and freedom) and conservatism (cultural, ethical, and religious aspects) that has stated about "The integrated growth of learners." It means that education must be able to be accessed regardless of social, economic, culture, geography, and ethnic background differences. This inclusive education ensures quality, equity and is consistently excellent (Kooli, $\underline{2020})$.

In addition, Kooli (2019b) has stated that the education philosophy of Oman refers to both perennials and progressivism that refers to the openness to the world while conserving its Arabic-Islam cultures to keep the society to be able to pursue globalization while preserving its society from its poor impact.

Moreover, to achieve a high quality of inclusive early childhood education, the school must be led by a great leader, a great principal. A principal needs to ensure that collaboration among staff, teachers, students, parents, and the community can be implemented as a team. A principal needs to maximize the use of education resources. For further, a principal's roles as a school administrator in inclusive education are in the tasks of sense-making, promoting inclusive cultures and practices in school, and building positive relationships outside of the school that may foster a new form of inclusive education practices (Ackah-Jnr, 2018).

Principals play a critical role in transforming schools as they become effective and inclusive. Indeed, these successful programs would not have been developed without strong, active principal support. 
This included demonstrating expertise at building a vision and setting direction, understanding and developing people and redesigning the school to support teachers (Waldron, 2015).

However, although it is important to prepare human resources and its leader for "Golden Indonesia 2045 ", there are few studies related to the combination of these two themes. Three research questions guide this paper: 1) What is the importance of inclusive early childhood education, 2) What is the key success of inclusive early childhood education, and 3) What is considered effective leadership of principal at inclusive early childhood education to optimize the preparation of facing "Golden Indonesia 2045”?

This paper is an effort to contribute to a high quality of inclusive early childhood education and effective leadership to help make Indonesia ready for "Golden Indonesia 2045".

\section{Literature review}

\section{Education for Indonesian golden generation}

Indonesian golden generation refers to Indonesia's future generation in which between 2035 and 2045 , Indonesia is going to have its demography bonus that the population's average age is between 35 and 45. BPS-Statistics (2017) recorded that the number of young population is more than the old ones. From its data, the number of people aged $0-9$ is 45,93 million while those aged $10-19$ is 43.55 million. It is projected that in 2045 , people who are now $0-9$ years old will be $35-45$ years old, while those whose ages are now $10-20$ will be $45-54$ years old. These people are called the "Golden Generation." This generation benefits Indonesia to become a developed country, more ready to take any opportunities and challenges. For this to become true, education plays a vital role because it may change behaviors and enrich the knowledge of humans. This is in line with Law of the Republic of Indonesia Number 20 of 2003 concerning the National Education System, states that: "Education is conscious and planned effort to create a positive atmosphere in the learning process so that students actively develop their potential to have spiritual strength, self-control, personality, intelligence, noble characters, and the skills needed by themselves, society, nation and state" (Indonesia, 2003). Referring to its statement, education needs planning to create an educational environment and learning process for students to develop their potential to gain religious strength, self-control, morals, intelligence, and skills for themselves, community, nation, and country.

According to Darman (2017), achieving Indonesian golden generation needs to improve Indonesia's education quality, as follows: (1) increasing education budget, that government has a responsibility for funding education for citizens; (2) managing education; (3) making the school free from businessminded; (4) fixing the curriculum; (5) giving more attention to religion; (6) training critical awareness, and; (7) empowering teachers. Since education is one of the basic human rights, every child has to participate in education.

Early childhood education takes an important role as basic formal education. In addition, early childhood education requires children aged 4-6 years to get stimulation in six developmental areas. They are Moral Value and Religion; Physic and Motoric; Cognitive; Social - Emotional; Language; Art and Creativity (Permendikbud, 2014b). Through play, children in early childhood education get stimulation for those six areas to train their life skills and readiness to go to the next level of education.

\section{Inclusive early childhood education}

The growth of developmental delay birth requires early childhood education to apply "Education for All." This indicates that education must accommodate all children with all their conditions and uniqueness, for ordinary and developmental delay/disabled children. Early childhood education plays an important role in carrying inclusive education, since in this education level, six developmental areas are given main attention through schools' programs and activities. Moreover, children aged below six cannot be judged as special needs children yet without the recommendation from the expert through series of developmental tests and special observation. Indonesia's early childhood education 
curriculum framework supports the program and activities to maximize the development of the children with the six components below Nurdiana and Sunarsih (2016).

\section{Moral value and religion}

Children are introduced about their religion and are trained to do simple pray according to his/her religion; being honest; helpful; polite; respect; care of him/herself and their environment; recognize big days of each religion and tolerance toward other religions.

Physic-Motoric skills

a. Gross Motor Skills: Children have good coordination of body movement, supple; have good body balance; and are active and follow the rules.

b. Fine Motor Skills: Children can use kinds of equipment for exploration and have good selfexpression in various ways.

c. Health Care and Safety Manner: Children have their ideal weight, height and head circumference according to their ages; children also can perform hygienic life, are healthy and care about their safety.

\section{Cognitive competence}

a. Problem Solving: Children can solve simple daily problems in a flexible way that can be socially accepted and can apply their knowledge and experiences.

b. Thinking Logically: Children understand the concept of diversity; are able to classify objects; understand the concept of patterns; have good initiative; well-organized and understand the concept of cause and effect.

c. Symbolic Thinking: Children recognize and do rote count 1-10; recognize alphabets and are able to represent various objects through drawing.

\section{Social-Emotional aspect}

a. Self - Awareness: Children perform their potential; aware of their feelings; are able to control their emotions and socialize well.

b. Responsibility toward Themselves and Others: Children know their rights; obey rules; control themselves and are responsible for their behaviors for everyone's goodness.

c. Pro-social Behaviors: Children are able to play with their peers; have empathy; good response; have a sense of sharing; appreciate others' rights and ideas; cooperative; tolerance and are polite.

\section{Language}

a. Language Reception: Children understand stories being heard; understand directions and rules; love and appreciate reading-related activities.

b. Language Expression: Children are able to ask and answer questions; are able to have two-way communication, and are able to give information about what they know.

c. Literacy: Children understand the relation among alphabet shapes and their phonic; copy alphabets and understand the meaning of words.

\section{Art and creativity}

Children are able to explore and express themselves through art activities. They express their imagination through music, movement and role-play; children appreciate artworks. Basic competencies specify those curriculum frameworks as guidelines for schools to arrange their school programs and teachers to arrange their class activities to stimulate children's six developmental areas. In case the schools find developmental delay/disable children in those six areas, they should have further communication with parents continued with doctor's checking and therapy from the therapist. In other words, the main task for teachers is only for stimulation, while further observation, checking, and the experts must handle intervention.

The program requires collaboration to improve the quality of inclusive education. Many researchers have agreed that collaboration is a very important success key to inclusive education (Ackah-Jnr, 2018; Buysse \& Hollingsworth, 2009; Florian, 2017; Skrtic, Sailor, \& Gee, 1996). Inclusive schools 
need to work hard to achieve ideal inclusive education. Therefore, at least four education parties (government, parents, school, and community) need to collaborate, and each party has its works that need to be synergized.

In terms of school, inclusive education needs to have a solid supporting system. The basic curriculum needs to be adjusted to be reached by all students. Teachers' perceptions towards different conditions among students should be widely opened and acceptable. This requires high creativity and mindful teachers for the challenging task of accommodating various conditions of their students.

The ways for supporting teachers can be by the help of psychologists, therapists, and training related to curriculum and strategies to carry education inclusively. The ways to include the autistic children in-class activities can be carried out through small flashcards of school's activities/places, for autism to adjust rather than through verbal instructions that only can be followed by ordinary children. The changes in activities that occur suddenly are also challenging for autistic children so that teachers need to have suitable strategies to minimize their tantrum reactions. The closed question or minimizing the words when giving instruction will help the autistic children understand. Meditation and yoga are good for children with developmental delays to minimize their tantrums. Those examples require extensive knowledge from the teachers.

Previous studies have reported a strong connection between the quality of inclusive early childhood education and professional centers to especially focus on the program and the service for children, including the children with developmental delay or disable ones (Buysse \& Hollingsworth, 2009). Teachers also need to communicate with the parents about their children. Parents need to really participate and support schools' programs, actively communicating positively with school and teachers about their children's condition, their expectations towards their children, and the habits of their developmental delay/disable children.

Being opened is important. Supporting the school and accepting their children's condition will make inclusive education easier to run. Honig (1979) outlined advantages to involve parents in group meetings: (1) increasing parental self-awareness; (2) giving knowledge of ways to motivate children; (3) taking expression of parental needs; (4) giving knowledge about home management skills; (5) making and learning to use inexpensive home learning materials; (6) increasing self-esteem in the family; (7) helping parents acquire job skills.

In Early Childhood Education, the family takes an important role. Even though the program and curriculum in early childhood education have proposed and carried out exciting and creative activities, its program and curriculum have not paid much attention to the importance of home activities that can stimulate children's growth and development. The number of families that really pay more attention to growing their children has been decreased. Families are busy with their mobility, hardworking, and taking their part as single parenting. Cooperation among neighbors, institution, and schools are needed to boost positive energy for actualizing parents' participation in early childhood education. This kind of commitment must be a high political priority for national human resources for our future generation (

Supporting the collaboration idea is necessary to carry inclusive education; Community plays an important role for ideal inclusive education. How the community can accept developmental/disable children is going to affect the success of inclusive education. Inclusive education refers to the principle that the local schools need to accommodate all children within their diversity, although some interpretations relate to inclusive education practices.

According to Florian (2017), the heart of inclusive education is a collaboration among teachers, other professionals, students and parents. Socio-psychological factors play in inclusive schools that everyone at the school needs to accept differences and include all students in school activities that can accommodate all differences. Further, Florian outlined 4 characteristics of inclusion: (1) access, (2) collaboration, (3) achievement, and (4) diversity. 
Buysse and Hollingsworth (2009) supported that there should be advocating to build the connection between school programs and professional development to maximize the service for disabled children and their families for running inclusive education. Another research has mentioned that we need to highlight what the education parties (government, education system, schools, teachers, educators, parents and public practitioners) need to follow global and national statement about the importance and benefits of quality and fair, inclusive education (Ackah-Jnr, 2018). The theory of inclusive education has proposed its philosophy, policies and practices. Those are combined in order to build special and inclusive education. The aim of special inclusive education is to facilitate inclusive students so they will be ready to contribute as part of community (Hornby, 2015).

In fact, the research in Oman has shown that high education levels are still reluctant to accept students' differences of abilities that make its education programs do not meet the needs of students. The improvement requires affirmation, recognition, and recommendation taken from each high education level's report for helping an institutional audit team describe its high education level (Kooli, Jamrah, \& Al-Abri, 2019).

\section{Leadership Styles}

A good leader assures the organization he leads is going to develop and grow. A leader has complicated tasks since the organization's growth and failure depend on the way he leads.

In term of inclusive education in early childhood education, many schools have run inclusive education though they are not claimed as inclusive schools. On the other hand, many of those schools are not well-directed yet to run quality inclusive education and do not have an effective leader as an administrator.

Riehl (2000) explored the roles of administrators when reacting to various students' needs. Three tasks of principal as a school administrator that need to be underlined are: developing the new meaning of diversity, promoting inclusivity related to school's culture and its teaching programs, and promoting the relation among school and community that in fact, the research of Kooli et al. (2019) has shown that in Oman, there are many high education levels hold programs without awareness of students' needs and abilities while an audit panel has not focused on evaluating high education levels' performances. Riehl offered a positive perspective about the potential of principals to be included in the practice of inclusive and transformative education. When it is related to the unending commitment toward equality, voices and social justice, the efforts of administrator are to build and to promote the nature of inclusion at the school and keep positive relation among the school and education parties and community around, so the leader is going to be able to perform new inclusive education practice.

In addition, Park, Jeong, Jang, Yoon, and Lim (2018) reviewed research about conceptual framework that demonstrates core dimension, competency and the behavior of an effective global leader that should have big respect toward cultural diversity; good interpersonal; ability to think globally; is able to accept and works on the change; strong vision; good personalities and moral values; good ethic; open-mindedness and flexibility. For further, Park et al. examined correlation among the dimension of Bass leaderships (transformational, transactional and laissez-faire) and some result variables (employees' extra effort, employees' satisfaction toward leader and leadership affectivity) and organizational commitment. Discussing conceptual framework and complete leadership styles by Bass and Stogdill (1990) about transformational, transactional and laissez-faire leadership, Park et al. discussed the ability and characteristics of transformational leadership. He observed organizational commitment. His study result indicates that effective leadership and committed employees are needed to fulfill the demand for education.

Hariri, Monypenny, and Prideaux (2016) revealed that transformational leadership and rational decision-making affect the satisfaction of the teachers; this finding might affect the quality of teachers' work. In addition, Masruri (2014) found from his research analysis that there are total and partial connections about principals' leadership towards the organization nature; the better the leadership of the principal, the better they will provide the belief of organizational culture 
improvement. Nguyen, Mia, Winata, and Chong (2017) found that the transformational leadership style is able to actualize the education vision and maximize the contribution of organization followers (in this term: education parties) through everyone's effort to gain education goal.

Leadership styles play a prominent part in holding quality organization. Theories of leadership come from Greatman Theory, Trait Theory, Behavioral Theory, Participate Theory, Contingency Theory, to Contemporary Leadership Theory. This leadership theory evolution has been raised adjusting the new era. Nowdays, Exemplary leadership (Kouzes \& B. Posner, 2012; Kouzes \& Posner, 2003, 2007; J. M. Kouzes \& B. Z. Posner, 2012; Kouzes \& Posner, 2014; Posner, 2015, 2016; Posner \& Kouzes, 1988) becomes major research around the world, such as San Fransisco, Australia, New Zealand that Kouzes and posner researched, Nigeria (Ogboso \& Amah, 2016), Malaysia (Salleh \& Khalid, 2018), America and New Zealand (Clavelle \& Prado-Inzerillo, 2018; Goewey, 2012) for various kinds of organizations (education, health, economic, social, politic and religion). From many leadership styles theories, it is important to have many types of research and examine exemplary leadership practices to prepare $21^{\text {st }}$-century leaders (Landis, Hill, \& Harvey, 2014). This can be a good donation for countries that need to make a revolution of education like what we can see from Oman, which is perceiving the evaluation of high education performances is strategically enforced are only made for accountability rather than an effective mechanism of the establishment. However, by an effective leadership style, there is a new insight into the education process and enhanced quality of governance and management in high education levels (Kooli, 2019a).

Exemplary leadership has five practices. They are: Model the Way, Inspired a Shared Vision, Challenge the Process, Enable Others to Act and Encourage the Heart. Model the way can be applied by a leader by being able to be a role model for others. Inspire a shared vision means the belief of a leader that they can make a change for a better future. Challenge the process shows that a leader is brave to take risks and does innovation. Enable others to act displays collaboration, building trust and creating an enthusiastic team. Encourage the heart shows that a leader can appreciate individual contributions and celebrate small wins. The practices and commitment of exemplary leadership are shown in this table.

Table 1. Exemplary leadership practices and commitments

\begin{tabular}{|l|l|}
\hline \multicolumn{2}{|c|}{ The Five Practices and Ten Commitments of Exemplary Leadership } \\
\hline Model the Way & $\begin{array}{l}\text { 1. Clarify values by finding your voice and affirming shared values. } \\
\text { 2. Set the example by aligning actions with shared values. }\end{array}$ \\
\hline Inspire a Shared Vision & $\begin{array}{l}\text { 3. Envision the future by imagining exciting and ennobling } \\
\text { possibilities. } \\
\text { 4. Enlist others in a common vision by appealing to shared } \\
\text { aspirations. }\end{array}$ \\
\hline Challenge the Process & $\begin{array}{l}\text { 5. Search for opportunities by seizing the initiative and by looking } \\
\text { outward for innovative ways to improve. } \\
\text { 6. Experiment and take risks by constantly generating small wins } \\
\text { and learning from experience. }\end{array}$ \\
\hline Enable Others to Act & $\begin{array}{l}\text { 7. Foster collaboration by building trust and facilitating } \\
\text { relationships. } \\
\text { 8. Strengthen others by increasing self-determination and } \\
\text { developing competence. }\end{array}$ \\
\hline $\begin{array}{l}\text { 9. Recognize contributions by showing appreciation for individual } \\
\text { excellence. } \\
\text { 10. Celebrate the values and victories by creating a spirit of } \\
\text { community. }\end{array}$ \\
\hline
\end{tabular}

Source: (J. M. Kouzes \& B. Z. Posner, 2012)

The health research in America has found that the characteristics of transformational leadership are in line with the characteristics of exemplary leadership so that exemplary leadership practices can be applied by transformational leaders in order to be inspiring, enthusiastic, holding open 
communication, supporting positive changing and giving affirmation through team decision making (Clavelle \& Prado-Inzerillo, 2018). The research in Australia and New Zealand has significantly proven that a leader who applies the practices of exemplary leadership creates positive engagement and performance of organization members (Posner, 2015).

From the literature above, one important thing to say is that to prepare the Indonesian golden generation 2045. Schools need a principal who applied exemplary leadership practices to run a high quality of inclusive early childhood education since exemplary leadership practices positively affect managerial ability. An effective leadership style of a principal will positively impact the level of school's commitment towards inclusive education.

\section{Research methodology}

This research used Google Scholar to find scientific information as sources and references to write a quality scientific article. The review process began with a search engine (Google Scholar) to search articles with keywords: "golden generation; inclusive; early childhood education; leader; leadership styles; exemplary leadership; principal; transformational leadership style". The search ranged was from any time. The criteria for inclusion in this study were as follows:

a. Qualitative results about demography bonus and future generation

b. Qualitative results about early childhood education

c. Qualitative results about inclusive education

d. Quantitative results of the relationship between organizational climate and organizational commitment

e. The research was conducted in Asia and Western

f. The research used English and Indonesia language

g. Dissertation and thesis are included.

Table 2. Inclusive Early Childhood Education and Leadership

\begin{tabular}{|c|c|c|c|}
\hline Author & Title & Country & Finding \\
\hline Darman (2017) & $\begin{array}{l}\text { Preparing } \\
\text { Indonesian Golden } \\
\text { Generation } 2045 \\
\text { through Quality } \\
\text { Education }\end{array}$ & Indonesia & $\begin{array}{l}\text { Golden generation is } \\
\text { Indonesia's population whose } \\
\text { ages are productive in } 2045, \\
\text { who mentally, spiritually and } \\
\text { ability have and use their } \\
\text { potential to make Indonesia a } \\
\text { developed country. Education } \\
\text { takes an important role in } \\
\text { preparing Indonesia's gold } \\
\text { generation, so we may adopt } \\
\text { education strategies from } \\
\text { developed countries to } \\
\text { maximize our education output. }\end{array}$ \\
\hline Manullang (2013) & $\begin{array}{l}\text { Characters } \\
\text { Education Grand } \\
\text { Design for Golden } \\
\text { Generation } 2045\end{array}$ & Indonesia & $\begin{array}{l}\text { Characters of Indonesia's gold } \\
\text { generation should refer to four } \\
\text { dimensions: Positive attitudes } \\
\text { toward "Pancasila (the Five } \\
\text { Principles)"; Essential thinking } \\
\text { to train children for having } \\
\text { critical thinking and becoming } \\
\text { problem solvers; Normative } \\
\text { commitment } \\
\text { Competencies. }\end{array}$ \\
\hline
\end{tabular}

Buysse and Program Quality United There should be a strong 
Hollingsworth (2009)

$\underline{\text { Honig (1979) }}$

Ackah-Jnr (2018)

$\underline{\text { Skrtic et al. (1996) }}$

Florian (2017) and Early

Childhood

Inclusion

Recommendations

for Professional

Development

Parents

involvement in

Early Childhood

Education

States

connection between inclusive schools and professional development to make quality inclusive education.

Since the first education comes from home and family, parents take their important parts for their children's success by fulfilling their both emotional and academic needs.

$\begin{array}{lrl}\text { System } & \text { and } & \begin{array}{l}\text { Some } \\ \text { studies } \\ \text { School-Level }\end{array} \\ \text { Resources } & \text { for } & \text { from some } \\ \text { Transforming } & \text { and } & \text { countries } \\ \text { Optimizing } & & \text { (Australia } \\ \text { Inclusive } & \text { and } \\ \text { Education in Early } & \text { America) } \\ \text { Childhood } & \text { for Ghana }\end{array}$

To run quality inclusive education, there should be preparation from school and teachers in responding to and fulfilling each child's different needs and maximizing education resources.

Settings: What

Ghana can Learn

Voice,

United

Collaboration, and

States

Inclusion

Democratic

Themes in

Educational and

Social Reform

Initiatives

(California, San Diego, Kentucky)

The basics of "voice, collaboration and inclusion" are included in three levels of reformation: structural reformation done at the school, pedagogical reformation done in the classroom, and institutional reformation done through community service at the community level.

Inclusive learning can happen when there are collaboration, problem-solving, personal awareness and learning motivation. Inclusive education has some advantages for all students.

Mentioning the importance of collaboration among education parties at the school (students, teachers, parents and other stake holders). Inclusion assures education equity that gives the school flexibility of its program refers to the government's policies about education. 


Veas, Castejón,
Miñano, and Gilar-
$\underline{\text { Corbí (2019) }}$

Park et al. (2018)
Relationship

between Parent

Involvement and

Academic

Achievement

through

Metacognitive

Strategies: A

Multilevel

Mediation

Analysis

Critical Review of

Global

Leadership

Literature:

Toward an

Integrative Global

Leadership

Framework

Antonakis and House (2013)

Hariri (2011)
The Full-Range

Leadership

Theory: The Way

Forward
Spain

There is a significant correlation between parents' involvement, metacognition and academic achievement.

Western
scholars,
particularly
from the
United
States

Western

A leader should have big respect toward cultural diversity; good interpersonal; ability to think globally; accept and work on the change; strong vision; good personalities and moral values; good ethics; open-mindedness and flexibility.

Transformational leadership comprises five factors: Idealized influence (attributed), idealized influence (behavior); Inspirational motivation; Intellectual stimulation and Individual consideration, while transactional leader shall consist of three factors: Contingent reward leadership; Management-by-exception active; Management - byexception passive. This research supports that transformational leadership is more positively associated with organizational effectiveness and followers' satisfaction.

Teachers prefer to have principals who have transformational and transactional leadership styles. The combination of them both has a significant and positive relationship but need to focus on a different area. Transformational leadership style needs to focus on various and comprehensive decisionmaking, while transactional leadership style needs to focus more on hand-tasking and 
Hariri et al. (2016)

Yahaya and Ebrahim $\underline{(2016)}$

Riehl (2000)

$\underline{\text { Posner (2015) }}$
Teacher-Perceived

Principal

Leadership Styles,

Decision-Making

Styles and Job

Satisfaction: How

Congruent are

Data from

Indonesia with the

Anglophile and

Western

Literature?

Leadership Styles

and

Organizational

Commitment:

Literature Review immediate problem-solving.

Lampung

Transformational leaders give employees more satisfaction because they put enough attention to individual needs, while transactional leaders only focus on rewards and punishment. The most ineffective leadership is laissezfaire. Mostly, principals perform transformational leadership style, less transactional and almost impossible for the principal to apply laissez-faire leadership.

In many areas (education, company, health care, military and bank), transformational leadership positively impacts employee productivity and their mental health. The combination of transactional and transformational leadership is the most effective style.

The Principal's Role in Creating

Around Inclusive Schools United for Diverse

Students: A

Review of

Normative,

Empirical, and

Critical Literature on the Practice of

Educational

Administration

States

An Investigation into the Leadership

Practices of

Volunteer Leaders
Transformation leadership in inclusive education can fulfill students' need for diversity; promote inclusion culture climate in school's environment; perform the good instructional program in teaching-learning and build good relationships among school and community.

Exemplary leadership practices are performed mainly by leaders from non-profit organizations, voluntary leaders, and leaders with many experiences. Model the way is not connected with genders and education level, but the ages of the leaders and "half-time working" leaders; enable others to act and encourage the heart are mostly performed by women than men; enable to act is not only give advantages for the teamwork but also for 


\begin{tabular}{|c|c|c|c|}
\hline$\frac{\text { Ogboso and Amah }}{\underline{(2016)}}$ & $\begin{array}{l}\text { Exemplary } \\
\text { leadership and } \\
\text { employee } \\
\text { engagement in } \\
\text { commercial banks } \\
\text { in Nigeria }\end{array}$ & Nigeria & $\begin{array}{l}\text { The research is about three } \\
\text { practices of exemplary } \\
\text { leadership (Model the Way, } \\
\text { Inspired a Shared Vision, and } \\
\text { Enable Others to Act) in some } \\
\text { chosen banks in Nigeria. The } \\
\text { result shows that those } \\
\text { exemplary practices } \\
\text { significantly impact } \\
\text { companies' progress and } \\
\text { intensify employees' optimal } \\
\text { performances. }\end{array}$ \\
\hline $\begin{array}{l}\text { Salleh and Khalid } \\
\underline{(2018)}\end{array}$ & $\begin{array}{l}\text { Effectiveness of } \\
\text { Principals } \\
\text { Exemplary } \\
\text { Leadership } \\
\text { Practiced on } \\
\text { School } \\
\text { Achievements: } \\
\text { Stakeholders' } \\
\text { Perceptions }\end{array}$ & Malaysia & $\begin{array}{l}\text { The research in Malaysia has } \\
\text { found stakeholders' perceptions } \\
\text { about a principal's } \\
\text { effectiveness who applies } \\
\text { exemplary leadership practices } \\
\text { toward school achievement. It } \\
\text { has shown that "Enable Others } \\
\text { to Act" is the most effective } \\
\text { practice, the second is } \\
\text { "Challenge the Process," } \\
\text { "Encourage the Heart" is the } \\
\text { third, the fourth is "Inspired a } \\
\text { Shared Vision," and the last is } \\
\text { "Model the Way." }\end{array}$ \\
\hline $\begin{array}{l}\text { Kuznetsov and } \\
\text { Fedorchuk (2019) }\end{array}$ & $\begin{array}{l}\text { Research in } \\
\text { Community } \\
\text { Competency of } \\
\text { School } \\
\text { Administrators } \\
\text { within Professional } \\
\text { Standard } \\
\text { Development. }\end{array}$ & & $\begin{array}{l}\text { An excellent } 21^{\text {st }} \text { school } \\
\text { leadership requires a principal } \\
\text { who can reinforce teaching } \\
\text { learning quality, develop } \\
\text { students potential adjusted } \\
\text { with diversity cultures and } \\
\text { education levels, hold } \\
\text { education for all, prepare the } \\
\text { community and carrer } \\
\text { opportunities for students, and } \\
\text { reinforce a school as a } \\
\text { comfortable, respectful and } \\
\text { intellect place. }\end{array}$ \\
\hline
\end{tabular}

\section{Results and discussions}

Prior to the result of the literature reviews shown in the table above concluded that for preparing "Golden Generation" for "Golden Indonesia 2045", education takes an important role. As a developing country, Indonesia is suggested to adopt education strategy taken from developed countries (Manullang, 2013), as can be acquired from sixteen Education philosophy of Oman that accepts internationalization and globalization through modernism while keeping traditional values as a foundation of life (Kooli, 2019b, 2020).

Early childhood education as a basis of education should be able to facilitate children's rights with their diversity and disability that refers to "Education for All." A primary concern for having quality 
education that has a new insight about the learning process and management enhancement (Kooli, 2019a) is all schools need to become inclusive education which can be started in an early childhood education as a basic foundation of formal education and the education level in which six development areas of the children are stimulated.

Inclusive education in this recent time applies "full inclusion," does not only give advantages for developmental delay/disabled children but also for ordinary ones: students who are gifted could be in a normal environment as a part of the community; students whose academic abilities are low will be able to perform their best; students who have learning difficulties will gain positive and effective support from their environment to maximize their success (iehl, 2000; $\underline{\text { Skrtic et al., 1996). }}$ ).

The success key aspect of inclusive education is collaboration from education parties. They are government, schools, teachers, students, parents, experts and the community. Each part has its own role but is connected and inseparable (Ackah-Jnr, 2018; Buysse \& Hollingsworth, 2009; Florian, 2017; Honig, 1979; Skrtic et al., 1996; Veas et al., 2019).

Effective leaders have become an important requirement for leading quality inclusive education (Antonakis \& House, 2013; Hariri, 2011; Hariri et al., 2016; Park et al., 2018; Riehl, 2000; Yahaya \& Ebrahim, 2016). This model has proved that great leaders are those who have a transformational leadership style. The combination of both transformational and transactional leadership styles is an effective way (Hariri, 2011; Yahaya \& Ebrahim, 2016) who has significant and positive relationships but needs to focus on different areas. While the transformational leadership style needs to focus on various and comprehensive decision-making, the transactional leadership style needs to focus more on hand-tasking and immediate problem solving (Hariri, 2011). None of the researchers have mentioned positive things about the laissez-faire leadership style. In line with the characteristics of transformational leadership, five practices of exemplary leadership can be frameworks for effective leadership.

By applying exemplary leadership practices, a principal will hold an effective school, develop resources, and maximize the school's potency. Exemplary leadership is aligned with transformational leadership characteristics that are charismatic, good decision maker, stimulating intelligence, and inspiring motivation (

Exemplary leadership practices are essential components for a leader to be able to perform transformational leadership. Transformational leaders do "Modelling the Way" because they believe what they say must be in line with what they do, so they are able to be role models for others. Transformational leaders do "Inspiring a Shared Vision" practice in positive and enthusiastic ways. Transformational leaders apply the practice of "Challenging the Process" through learning from mistakes for self-improvement. Transformational leaders do "Enabling Others to Act" practice by creating a conducive environment to make people perform their best. "Encourage the Heart" is the practice of transformational leaders by giving individual appreciation and strengthening the bond among the organization's members (Abu-Tineh, Khasawneh, \& Omary, 2009).

\section{Conclusion}

Recently, Indonesia is preparing "Golden Indonesia 2045", and education takes an important role. The main point to be done in education is running quality inclusive education that can facilitate diverse students, including children with developmental delays or special needs students, or developmental disabilities. Inclusive education is ideally started in early childhood education because six developmental areas are stimulated to be more ready to have a higher level of education in this level of education.

Collaboration among education parties is the success key for holding quality of inclusive early childhood education. The family takes the first role by being aware of the condition of the children. Acceptance of the community then will help special needs children to contribute their best. The 
government put the biggest authority by making laws to monitor schools for "Education for All" program that can facilitate students with diverse cultures, religions, and abilities/disabilities.

For running high-quality inclusive early childhood education, a great leader that we call "a principal" who must have an effective leadership style is needed. The principal must be able to be leaders of the $21^{\text {st }}$ century and lead the school as an institution to prepare "Gold Generation" to make Indonesia a developed country. Based on literature reviews, the effective leadership style to be implemented by a principal is a transformational leadership style. In line with effective leadership style, transformational fits the concept of exemplary leadership practices sounded by Kouzes and Posner (Keith \& Levin, 2002; Kouzes \& Posner, 2007; Kuznetsov \& Fedorchuk, 2019; Posner, 2015, 2016; Posner \& Kouzes, 1988).

Exemplary leadership practices refer to five practices. They are model the way in which leaders are able to be a role model for their followers because leaders' behavior will affect followers' respect toward them; inspire a shared vision, that leaders should have innovation and make the organization they lead having better quality than before; challenge the process shows leaders' ability to appreciate and take challenges positively for them to grow better. Leaders accept the idea from others and learn from mistakes; enable others to act, that leaders are empowering their followers to be strong, capable and connected one to each other to maximize followers' potential and the ability for reaching team's achievement; encourage the heart means that leaders appreciate and recognize followers' effort verbally and through their positive gestures. They celebrate even the small success of the team. Leaders care about their followers and have emotionally bonded with their followers. By having a transformational style that consistently does five exemplary leadership practices, a principal is going to promote the golden generation towards golden Indonesia 2045 (Abu-Tineh et al., 2009).

\section{Limitation and study forward}

As with research, this review is mainly limited to the literature review in the Indonesian context. However, this limitation is an opportunity for further research to widen the scope, primarily to conduct empirical research on this topic in an Indonesian school context.

\section{Acknowledgment}

We dedicate this work to Universitas Lampung and Sekolah Darma Bangsa for their academic and financial support.

\section{References}

Abu-Tineh, A. M., Khasawneh, S. A., \& Omary, A. A. (2009). Kouzes and Posner's transformational leadership model in practice: The case of Jordanian schools. Journal of Leadership Education, 7(3), 265-283.

Ackah-Jnr, F. R. (2018). System and school-level resources for transforming and optimising inclusive education in early childhood settings: What Ghana can learn. European Journal of Education Studies, 5(6), 203-220. doi:10.5281/zenodo.1494880

Antonakis, J., \& House, R. J. (2013). The full-range leadership theory: The way forward. Transformational and Charismatic Leadership: The Road Ahead 10th Anniversary Edition, 333. doi:10.1108/S1479-357120130000005006

Bass, B. M., \& Stogdill, R. M. (1990). Bass \& Stogdill's handbook of leadership: Theory, research, and managerial applications: Simon and Schuster.

BPS-Statistics, I. (2017). Statistics Indonesia. Bappenas \& United Nations Development Programme.

Buysse, V., \& Hollingsworth, H. L. (2009). Program quality and early childhood inclusion: Recommendations for professional development. Topics in early childhood special education, 29, 119-128. doi: $10.1177 / 0271121409332233$

Clavelle, J. T., \& Prado-Inzerillo, M. (2018). Inspire others through transformational leadership. American Nurse Today, 13(11), 39-41.

Darman, R. A. (2017). Mempersiapkan generasi emas indonesia tahun 2045 Melalui Pendidikan Berkualitas. Edik Informatika, 3(2), 73-87. 
Florian, L. (2017). The heart of inclusive education is collaboration. Pedagogika, 126(2), 248-253. doi: $10.15823 /$ p.2017.32

Goewey, D. F. (2012). Examining the Kouzes and Posner leadership practices of elementary principals in central New York.

Hariri, H. (2011). Leadership styles, decision - making styles, and teacher job satisfaction: In Indonesian school context. (Doctor Thesis), James Cook University Australia, Australia.

Hariri, H., Monypenny, R., \& Prideaux, M. (2016). Teacher-perceived principal leadership styles, decision-making styles and job satisfaction: how congruent are data from Indonesia with the Anglophile and Western literature? School Leadership \& Management, 36(1), 41-62. doi:10.1080/13632434.2016.1160210

Hay, I. (2006). Transformational leadership: Characteristics and criticisms. E-journal of Organizational Learning and Leadership, 5(2).

Honig, A. S. (1979). Parent involvement in early childhood education (Vol. 1934): National Association for the Education of Young Children Washington, DC.

Hornby, G. (2015). Inclusive special education: Development of a new theory for the education of children with special educational needs and disabilities. British Journal of Special Education, 42, 234-256. doi:10.1111/1467-8578.12101

Undang-undang Republik Indonesia nomor 20 tahun 2003 tentang sistem pendidikan nasional, (2003).

Jamrah, A. (2017). Shaping golden generation through character education toward 100 years Indonesia. Proceeding IAIN Batusangkar, 1(2), 41-50.

Keith, A., \& Levin, L. (2002). The five practices of exemplary leadership (4th Edition ed.).

Kooli, C. (2017). Transformation du système éducatif Omanais, quarante ans de formation de capital humain: évolution et performance. Paris, EHESS.

Kooli, C. (2019a). Governing and managing higher education institutions: The quality audit contributions. Evaluation and program planning, 77, 101713.

Kooli, C. (2019b). The philosophy of education in the sultanate of Oman: Between perennialism and progressivism. American Journal of Education and Learning, 4(1), 36-49.

Kooli, C. (2020). The philosophy of education in the Sultanate of Oman: between conservatism and modernism. International Journal of Knowledge and Learning, 13(3), 233-245.

Kooli, C., Jamrah, A., \& Al-Abri, N. (2019). Learning from Quality Audit in Higher Education Institutions: A Tool for Community Engagement Enhancement. FIIB Business Review, 8(3), 218-228.

Kouzes, \& Posner, B. (2012). The leadership challenge: How to make extraordinary things happen in organizations . San Francisco. CA: The Leadership Challenge.

Kouzes, J. M., \& Posner, B. Z. (2003). Leadership practices inventory: Pfeiffer San Francisco, CA.

Kouzes, J. M., \& Posner, B. Z. (2007). The five practices of exemplary leadership (Second Edition ed.). United States: John Willey \& Son, Inc.

Kouzes, J. M., \& Posner, B. Z. (2012). The Leadership Challenge Workbook. San Francisco: JosseyBass. A Wiley Imprint.

Kouzes, J. M., \& Posner, B. Z. (2014). Extraordinary leadership in Australia and New Zealand: The five practices that create great workplaces: John Wiley \& Sons.

Kuznetsov, A., \& Fedorchuk, Y. (2019). Research in Community Competency of School Administrators within Professional Standard Development. Paper presented at the International Conference on the Development of Education in Eurasia (ICDEE 2019).

Landis, E. A., Hill, D., \& Harvey, M. R. (2014). A synthesis of leadership theories and styles. Journal of Management Policy and Practice, 15(2), 97.

Manullang, B. (2013). Grand Desain Pendidikan Karakter Generasi Emas 2045. Jurnal Pendidikan Karakter, 1, 14.

Masruri, H. (2014). Pengaruh kepemimpinan kepala sekolah, kompetensi guru dan motivasi kerja guru terhadap budaya organisasi serta implikasinya pada kinerja guru. Kontigensi: Scientific Journal of Management, 2(2), 55-67.

Nguyen, T. T., Mia, L., Winata, L., \& Chong, V. K. (2017). Effect of transformational-leadership style and management control system on managerial performance. Journal of Business Research, 70, 202-213. doi:10.1016/j.jbusres.2016.08.018 
Nurdiana, J., \& Sunarsih, C. (2016). Modul guru pembelajar taman kanak - kanak kelompok kompetensi C. Bandung: Pusat Pengembangan dan Pemberdayaan Pendidik dan Tenaga Kependidikan Taman Kanak-Kanak dan Pendidikan Luar Biasa, Direktorat Guru dan Tenaga Kependidikan.

Ogboso, O. C., \& Amah, E. (2016). Exemplary leadership and employee engagement in commercial banks in Nigeria. International Journal of Managerial Studies \& Research, 4(2), 16-26.

Park, S., Jeong, S., Jang, S., Yoon, S. W., \& Lim, D. H. (2018). Critical review of global leadership literature: Toward an integrative global leadership framework. Human Resource Development Review, 17(1), 95-120. doi:10.1177/1534484317749030

Peraturan Menteri Pendidikan dan Kebudayaan no. 137 Tahun 2014 Tentang Standar Nasional Pendidikan Anak Usia Dini, (2014a).

Peraturan Menteri Pendidikan dan Kebudayaan No. 146 Tahun 2014 tentang Kurikulum 2013 PAUD, (2014b).

Peraturan Mentri Pendidikan Nasional Nomor 70 Tahun 2009 tentang Pendidikan Inklusif bagi Peserta Didik yang Memiliki Kelainan dan Memiliki Potensi Kecerdasan dan/atau Bakat Istimewa, 70 C.F.R. (2009).

Posner, B. Z. (2015). An investigation into the leadership practices of volunteer leaders. Leadership \& Organization Development Journal. doi:10.1108/LODJ-03-2014-0061

Posner, B. Z. (2016). Investigating the reliability and validity of the Leadership Practices Inventory®. Administrative Sciences, 6(4), 17. doi:10.3390/admsci6040017

Posner, B. Z., \& Kouzes, J. M. (1988). Development and validation of the leadership practices inventory. Educational and psychological measurement, 48(2), 483-496. doi: $10.1177 / 0013164488482024$

Riehl, C. J. (2000). The principal's role in creating inclusive schools for diverse students: A review of normative, empirical, and critical literature on the practice of educational administration. Review of educational research, 70(1), 55-81. doi:10.3102/00346543070001055

Salleh, M. J., \& Khalid, R. (2018). Effectiveness of principals exemplary leadership practiced on school achievements: stakeholders' perceptions European Journal of Education Studies.

Skrtic, T. M., Sailor, W., \& Gee, K. (1996). Voice, collaboration, and inclusion: democratic themes in educational and social reform initiatives. Remedial and Special Education, 17(3), 142-157. Retrieved from rse.sagepub.com website:

Veas, A., Castejón, J. L., Miñano, P., \& Gilar-Corbí, R. (2019). Relationship between parent involvement and academic achievement through metacognitive strategies: A multiple multilevel mediation analysis. British Journal of Educational Psychology, 89(2), 393-411. doi:10.1111/bjep.12245

Waldron, J. M. N. L. (2015, June 12). Effective leadership makes schools truly inclusive. kappanmagazine.org, 96.

Yahaya, R., \& Ebrahim, F. (2016). Leadership styles and organizational commitment: literature review. Journal of Management Development, 35(26). doi:10.1108/JMD-01-2015-0004 